\title{
Tentang Problem Hewan dalam Diskursus Filsafat Barat
}

\author{
Muhammad Unies Ananda Raja \\ Mahasiswa S1 IImu Filsafat \\ Universitas Gadjah Mada
}

\begin{abstract}
Abstrak
Artikel ini bertujuan untuk mengetahui apa yang dimaksud dengan problem hewan atau pertanyaan mengenai hewan dalam diskursus filsafat Barat. Secara singkat, problem hewan itu menyangkut dua hal: esensi dan distingsi. Pertanyaan penting dalam problem hewan adalah mengenai kemungkinan untuk mendefinisikan esensi hewan itu sendiri yang berbeda dari manusia. Selain itu, mempertanyakan landasan dan asumsi-asumsi tertentu mengenai distingsi manusia-hewan. Dalam kerangka ini, esensi hewan sebagai hewan yang didefinisikan secara oposisional dengan manusia selalu problematis karena ciri yang membedakan itu tidak pernah stabil karena memiliki basis argumen yang lemah. Dengan begitu, distingsi manusia-hewan tidak memiliki sokongan filosofis yang kuat dan mesti dipertanyakan kembali.
\end{abstract}

Kata Kunci: problem hewan, esensi, distingsi, hewan, animal studies

\section{Pendahuluan}

Dalam diskursus filsafat, khususnya tradisi Barat, hewan selalu dioposisikan dengan manusia. Hewan dianggap sebagai makhluk yang tidak mempunyai (lack) sesuatu yang dimiliki manusia. Contohnya, menurut Aristoteles, apa yang membedakan manusia dengan hewan adalah bahasa (Bourke, 2013: 7). Manusia memiliki bahasa yang membuatnya punya kemampuan untuk membedakan apa yang baik dan apa yang buruk (the just and unjust; the good and evil). Hewan, di sisi lain, hanya punya suara atau dalam istilah Aristoteles a mere voice. Suara ini bukan bahasa. Suara menandakan kesenangan (pleasure) dan kepedihan (pain). 
Contoh di atas hanyalah salah satu dari sekian banyak contoh. Giorgio Agamben menyatakan bahwa dalam diskursus filsafat (Barat) problem mengenai makhluk hidup tidak pernah didefinisikan secara jelas. Seperti yang ia sampaikan;

"segalanya terjadi seakan-akan, dalam kebudayaan kita [Barat], kehidupan [life; kata ini merujuk pada kehidupan biologis dan bukan eksistensial] adalah apa yang tak bisa didefinisikan, namun, karena itu harus terus-menerus diartikulasikan dan dibagi-bagi [divided]." (Agamben, 2002: 13)

Pasca Aristoteles berbagai filsuf terus mencari apa yang membedakan manusia dan hewan. Hal ini akan dieksplorasi lebih lanjut di bagian selanjutnya. Singkat cerita, setelah berabad-abad diskursus filsafat menerima begitu saja distingsi manusia dan hewan, pada abad 20 muncul filsuf-filsuf yang menyuarakan kegelisahan mengenai hal itu. Untuk menyebut yang paling populer; Peter Singer dan Tom Regan. Mereka menyampaikan argumen-argumen yang menolak antroposentrisme yang kental di filsafat Barat. Tujuan mereka adalah untuk membentuk hak-hak hewan. Walaupun sebenarnya, jika ditilik lebih lanjut, argumen mereka banyak dipengaruhi oleh Jeremy Bentham. Bentham sendiri adalah salah satu filsuf yang menolak antroposentrisme dengan argumen tersohornya mengenai kemampuan hewan untuk mengalami rasa sakit (ability to suffer).

Wacana ini semakin berkembang hingga munculnya animal studies. Meski begitu, menurut Calarco (2008: 1), tidak ada definisi yang diterima secara luas. Namun, apa yang menjadi perhatian pemikir-pemikir yang mengidentifikasi diri atau diidentifikasi dalam lingkar animal studies adalah pertanyaan mengenai hewan atau "the question of the animal." Apa yang dipertanyakan dalam "the question" adalah apa yang disebut Derrida sebagai cara-cara para filsuf memandang hewan secara reduktif dan esensialis (Calarco, 2008: 4). Dari situ, Calarco (2008: 2) mengidentifikasi dua problem besar dalam animal studies. Pertama, pertanyaan mengenai hakikat hewan (animality). Kedua, pertanyaan mengenai distingsi menusia dan hewan.

Problem-problem tersebut saling berkaitan. Mengenai hakikat hewan sendiri, banyak filsuf yang mempertanyakan kemungkinan untuk mendefinisikan hewan secara homogen. Apakah ada esensi kehewanan dari banyaknya ragam hewan yang ada? Definisi hewan secara homogen ini berimbas pada pembentukan konsep "kehewanan" (animality) yang bertujuan untuk membentuk suatu demarkasi atau distingsi manusia dan hewan. Banyak teoretisi yang menolak hal ini, baik dari ranah filsafat maupun saintifik seperti biologi, karena "hewan tidak bisa direduksi dalam pemisahan yang 
sederhana atau kompleks dari karakteristik-karakteristiknya." (Calarco, 2008: 3) Jika tidak ada esensi "kehewanan" yang bisa didefinisikan secara jelas, baik filsofis maupun biologi, maka distingsi clear manusia-hewan tidak bisa dipertahankan.

Diskursus mengenai hewan, seperti sudah saya jelaskan sebelumnya, muncul sekitar abad 20. Cary Wolfe mengidentifikasi dua faktor yang menyebabkan maraknya diskursus mengenai hewan di ilmu kemanusiaan secara umum (Wolfe, 2003: x-xi). Faktor pertama adalah krisis humanisme dalam teori kritis yang dibawa oleh strukturalisme dan pascastrukturalisme dengan interogasi terhadap figur manusia yang konstitutif atau membetuk sejarah dan masyarakat. Tokoh-tokoh seperti Claude Levi-Strauss, Louis Althusser, Michel Foucault, dan Jacques Derrida berperan penting dalam perkembangan isme-isme tersebut. Faktor kedua adalah perubahan radikal mengenai sosok "hewan" dalam ilmu-ilmu di luar kemanusiaan. IImu-ilmu baru seperti cognitive ethology dan ekologi telah mengajukan pertanyaan mengenai validitas kategori-kategori yang digunakan untuk mempertahankan antroposentrisme, seperti bahasa, teknologi, dan kebudayaan. Banyak penelitian mengenai bahasa dan kognisi pada kera besar (giant apes) dan mamalia laut yang menunjukkan betapa tipisnya batas yang membedakan karakteristik biologis manusia dan hewan.

Dua faktor di atas berhubungan dengan apa yang telah saya sampaikan mengenai perhatian para pemikir dalam animal studies, yakni esensi "kehewanan" dan distingsi manusia-hewan. Dari situ, problem hewan bisa diturunkan menjadi dua hal:

1. Apakah mungkin mendefinisikan hewan sebagai hewan sebagai entitas yang general atau umum?

2. Jika ya, apa karakteristik hewan yang membedakannya dari manusia? Jika tidak, apa yang harus dilakukan dengan distingsi tersebut?

Mengenai pertanyaan pertama, Derrida berulangkali menyatakan bahwa hal itu tak mungkin dilakukan. Dalam Of Spirit (1989) ia menyatakan bahwa dalam menjelaskan hewan, filsuf-filsuf sebelumnya seringkali menggeneralisasi hewan dengan hanya menyebutkan beberapa contoh. Derrida (1989: 57):

"Tesis mengenai hewan mengasumsikan--hal ini adalah hal yang tidak bisa direduksi dan saya percaya adalah hipotesis dogmatis mengenai tesis tersebut--bahwa ada satu hal, satu domain, satu tipe entitas homogen yang bisa disebut hewan [animality] secara umum, yang dengan itu suatu contoh cukup untuk mendemonstrasikan tesis itu." 
Selain itu, dalam wawancaranya dengan Elisabeth Rudinesco, Derrida juga menjelaskan bahwa, "ada banyak jenis [multiciplity] makhluk hidup, banyak jenis hewan, beberapa di antaranya tidak bisa dimasukkan dalam wacana besar mengenai Hewan yang mengklaim untuk memberikan atribut tertentu atau merekognisi mereka." (Derrida, 2004: 63) Pada kesempatan lain, Derrida juga mengutarakan kegelisahan yang sama mengenai konsep hewan yang general ini.

"Kegelisahan kritis...akan diarahkan pada, pertama-tama, sekali lagi, penggunaan secara singular konsep yang umum seperti "Hewan", seakan-akan semua makhluk hidup nonmanusia bisa dikelompokkan dengan common sense dalam "tempat yang sama" ["commonplace"]" (Derrida, 2008: 34)

Menurut Calarco, pertanyaan pertama yang juga digelisahkan oleh Derrida itu berhubungan dengan pertanyaan mengenai kemungkinan untuk menjelaskan hewan sama sekali. Calarco (2008: 5):

"Apakah diskursus yang ada saat ini, entah yang diambil dari sains atau filsafat, dari sudut pandang antroposentris atau antroposentris, mampu untuk mendeskripsikan keberagaman bentuk makhluk hidup dan perspektif yang ditemukan di antara mereka yang kita sebut "hewan"?"

Pertanyaan kedua mengenai distingsi itu sendiri. Menurut Calarco (2008: 63), filsafat Barat sejak awal mulanya di Yunani telah mendasarkan diri pada susunan hirarkis manusia-hewan yang mengutamakan manusia. [Tentu saja definisi manusia ini juga problematis karena di kebudayaan Yunani kuno budak dan perempuan tidak dianggap benar-benar manusia.] Distingsi ini dibentuk dari karakteristik manusia yang tidak dipunyai oleh hewan. Seperti yang sudah saya jelaskan mengenai Aristoteles, menurutnya apa yang membedakan manusia dengan hewan adalah bahasa. Selain itu, menurut Aristoteles, apa yang membedakan manusia adalah rasionalitasnya. Seperti term terkenal yang mungkin semua orang mengetahuinya: rational animale. Namun, menurut Joanna Bourke, definisi mengenai manusia ini sangat tidak stabil. Bourke (2013: 4-5): "Di setiap periode sejarah dan kebudayaan, konstruksi common sense mengenai 'manusia' dan 'hewan' memang ada, tapi distingsi itu selalu dipertanyakan dan diperbarui."

Ada banyak kategori yang membedakan manusia: rasionalitas, bahasa, kesadaran, jiwa, kemampuan membuat teknologi, dan lebih banyak lagi. Sejak Aristoteles hingga Lacan distingsi itu selalu ada. Apapun definisi yang diberikan pada 
manusia, menurut Bourke, selalu mengimplikasikan eksklusi. Bourke (2013: 8) mengutip Bertram Lloyd:

"Menyangkal akal dari hewan, dan kau berarti juga menyangkalnya dari bayimu [infants]: mengafirmasi eksistensi jiwa abadi dalam bayimu atau dirimu, dan kau harus setidaknya memberi sesuatu hal yang sama untuk anjingmu."

Yang dimaksud Bourke adalah bahwa definisi tentang manusia itu tidak akan ada hentinya. Definisi itu tidak akan final. Mengutip Derrida kembali:

"Tidak satupun dari ciri-ciri yang dianggap mungkin untuk mengetahui 'apa yang benar-benar manusia' ['proper of man'] oleh filsafat atau kebudayaan yang paling berwenang sekali pun--tidak satupun di antaranya, dengan segala ketelitiannya [rigor], adalah apa yang eksklusif milik apa yang oleh kita manusia sebut sebagai manusia. Entah karena beberapa hewan memilikinya, atau karena manusia tidak memiliki ciri-ciri seperti yang diklaim." (Derrida, 2004: 66)

Dengan penjelasan ini, saya ingin menunjukkan bahwa distingsi manusia-hewan dibentuk oleh definisi mengenai apa yang, dalam istilah Derrida, 'proper of man.' Jika, merujuk pertanyaan pertama, esensi "kehewanan" itu tidak mungkin didefinisikan secara umum dan general karena keanekaragamannya dan definisi "kemanusiaan" itu juga problematis karena alasan yang sudah dijelaskan. Di bagian selanjutnya, saya akan menelusuri pemikiran beberapa filsuf dan ilmuwan penting di tiap zaman mengenai hewan dan memperlihatkan problem-problemnya dengan mendasarkan pada pertanyaan-pertenyaan mengenai hewan yang sudah dijabarkan sebelumnya.

\section{Pembahasan}

\section{A. Esensi}

Menurut Oxana Timofeeva (2016: 2), apa yang bukan manusia atau nonmanusia didefinisikan berdasarkan negativitas. Artinya, nonmanusia adalah apa yang bukan manusia. Mungkin itu adalah jawaban yang "superficial" dalam menjawab definisi nonmanusia. Namun, seperti yang akan dieksplorasi lebih lanjut, ini adalah definisi hewan dalam berbagai pemikiran filsuf dari Barat. Hewan adalah apa yang bukan manusia dan yang tidak memiliki sesuatu yang dimiliki secara spesial oleh manusia. 
Aristoteles membedakan manusia dan hewan berdasarkan kepemilikan bahasa. Manusia memiliki bahasa yang memungkinkannya berkomunikasi dalam polis dan membedakan baik-buruk. Hal ini dikarenakan:

"Aristoteles tidak mendefinisikan apa itu kehidupan [life; kalimat ini dalam konteks biologis, mungkin bisa diterjemahkan juga sebagai makhluk hidup]: ia membatasi dirinya dengan mencacah-cacah [breaking down], dengan mengisolasi nutritive function [bagaimana suatu entitas itu bertahan hidup], yang kemudian digunakan untuk mengartikulasikan kembali kehidupan itu sendiri pada rentetan perbedaan dan kemampuan [faculties] atau potensialitas [potentiality] (nutrisi, sensasi, pikiran)." (Agamben, 2002: 14)

Maka dari itu, apa yang dilakukan Aristoteles adalah mencari tahu apa yang membuat sesuatu itu termasuk dalam sesuatu hal. Aristoteles mendefinisikan makhluk hidup sebagai sesuatu yang mempunyai fungsi nutritive. Artinya, makhluk itu bisa tumbuh dan mati (growth and decay). Segala sesuatu yang tidak punya kemampuan itu adalah bukan makhluk hidup. Di sinilah perbedaan makhluk hidup dan bukan hidup.

Meski begitu, bagi Aristoteles, fungsi nutritive itu adalah apa yang menjadi kategori makhluk hidup secara fundamental. Ada beragam makhluk hidup yang tidak hanya memiliki kemampuan nutritive saja. Seperti yang ia sebutkan "pikiran, sensasi, gerak lokal dan diam, atau gerakan dalam konteks nutrisi, mati dan tumbuh." (Aristoteles, 1984: 658) Saat Aristoteles membicarakan tumb uhan dalam paragraf tersebut, ia menyebutkan bahwa fungsi nutritive adalah "satu-satunya potensi psikis yang mereka punya." Tumbuhan memang termasuk makhluk hidup, tapi ia hanya punya kemampuan nutritive. Tumbuhan tidak punya kemampuan sensasi atau berpikir.

Hal yang sama juga berlaku terhadap hewan. "Hewan" tak punya kemampuan berpikir, sebab rational adalah milik manusia. Sejak ada banyak makhluk hidup, Aristoteles mencari apa yang membedakan satu hal dengan hal lain. Tumbuhan berbeda dengan hewan, hewan berbeda dengan manusia, manusia berbeda dengan Tuhan. Apa yang telah dibedakan dan dipisah-pisah inilah yang membentuk suatu kesatuan kehidupan yang hirarkis berdasarkan "kemampuan fungsional dan perbedaannya." (Agamben, 2002: 14)

Tradisi pemikiran ini berlanjut hingga René Descartes (1596-1650). la menganggap bahwa hewan tak ubahnya sebagai mesin, sebuah automata. Hewan bergerak dan hidup karena mengikuti instingnya saja. Descartes (1985: 73--6): "adalah 
Alam yang bertindak dalam mereka sesuai dengan karakteristik organnya, seperti saat kita melihat jam," Descartes juga membedakan kemampuan kebahasaan manusia dan hewan. Descartes (1985: 140--141):

"Manusia lahir tuli dan bodoh, dan karenanya tidak punya (deprived) alat bicara seperti para binatang (beasts) atau bahkan lebih, biasanya menciptakan tanda-tandanya sendiri untuk membuat dirinya bisa dimengerti oleh orang-orang yang ada di sekitarnya yang punya waktu untuk mempelajari bahasanya. Bukti (witness) ini bukan hanya karena para binatang itu punya akal budi yang lebih rendah dari manusia, namun bahwa mereka tidak punya akal budi sama sekali...Dan kita tak boleh merancukan wicara (speech) dengan gerakan alami yang menjadi bukti mengenai insting (passion) dan yang bisa diimitasi oleh mesin dan juga hewan. Kita juga tak boleh berpikir, seperti orang zaman dahulu, bahwa para binatang berbicara, meski kita tidak tahu bahasa mereka."

Bagi Descartes, adalah suatu hal yang jelas bahwa hanya manusia yang memiliki akal budi atau rasionalitas. Hanya manusia yang mampu meragukan dirinya. Tindakan meragukan itulah yang membuat dirinya menjadi manusiawi.

Untuk mengakses Aku Murni, diri harus melepaskan diri dari dimensi ketubuhan, dimensi kehewanan. Bagi Descartes, apa yang tidak bisa dilepas dari manusia ialah berpikir itu sendiri. Cogito ergo sum. Menurut Descartes (1984: 18) "hanya ini yang tak terpisahkan dariku. Aku ada, Aku eksis ( $\mathrm{am}, \mathrm{I}$ exist)--ini sudah jelas. Tapi sampai berapa lama? Selama aku berpikir." Dimensi berpikir inilah yang menjadi pembeda manusia dan hewan. Manusia mempunyai kemampuan reflektif, kemampuan untuk lepas dari hasrat ketubuhannya, sebab itu adalah sesuatu yang tidak substansial bagi dirinya. Hal ini berbeda dengan hewan yang terjebak dalam instingnya atau dalam passion. Hewan tak punya "Aku". Seperti dijelaskan Derrida (2008: 76) dalam interpretasinya terhadap Descartes,

"relasi pada jiwanya sendiri dan pada pikirannya sendiri, Adanya suatu substansi yang berpikir, mengimplikasikan konsep mesin-hewan yang tak punya [deprived]...sang ego sebagai ego cogito, je pense. Automaton seperti itu tidak punya "aku" atau "diri" dan, lebih dari itu, kapasitas refleksi,"

Pada akhirnya, pandangan Descartes sendiri sama seperti Aristoteles. la memandang bahwa ada perbedaan signifikan yang amat besar yang membedakan manusia dan 
hewan. Manusia memiliki karakteristik spesial yang tak dimiliki oleh hewan, seperti bahasa dan akal budi.

Carolus Linnaeus (1707-1778), salah satu pelopor taksonomi modern, menolak pandangan Descartes mengenai hewan sebagai automaton. Dalam buku Systema naturae yang dikutip Agamben (2002: 23), Linnaeus menyatakan: "sudah pasti Descartes tidak pernah melihat kera." Linnaeus memang menyukai kera. Bagi Linnaeus, membedakan kera dan manusia dari sudut pandang sains tidaklah mudah. Linnaeus (1995: 4-5) dalam Agamben (2002: 24) menyatakan bahwa tidak ada "satu tanda yang membedakan manusia dan kera." Meski begitu, Linnaeus yang merupakan pencetus istilah Homo sapiens memberi pembedaan hewan dan manusia bukan dalam ranah sains. Bagi Linnaeus, manusia tidak punya identitas yang spesifik selain kemampuannya menyadari (recognize) dirinya sendiri. Seperti dijelaskan Agamben (2002: 25) dalam interpretasinya terhadap Linnaeus: "manusia adalah hewan yang harus menyadari dirinya sendiri sebagai manusia untuk menjadi manusia." Linnaeus melakukan ini karena ia tidak bisa menemukan perbedaan yang jelas antara manusia dan kera secara biologis. Maka dari itu, Homo sapiens adalah hewan yang menjadi manusia ketika ia menyadari bahwa ia bukanlah hewan. Dari segi filosofis, Linnaeus bisa dilihat tak begitu beda dengan Descartes yang menekankan kemampuan reflektif manusia sebagai pembeda dari hewan.

Terlahir di masa yang sama, Immanuel Kant (1724-1804) juga memiliki pemikiran yang mirip dengan para pendahulunya. Kant masih mempertahankan definisi manusia sebagai rational animal. la mempertahankan definisi ini dengan basis "Aku" (the I) (Derrida, 2008: 92). Yang dimaksud dengan "Aku" adalah "Aku yang berpikir." Kant memberikan penjelasannya dalam Anthropology from a Pragmatic Points of View (2006). Manusia didefinisikan sebagai makhluk yang punya kemampuan representasi "Aku." Menurut Derrida dalam interpretasinya terhadap teks Kant, "'Aku" menandakan kesatuan kesadaran yang tetap sama dalam berbagai modifikasinya....ia adalah kesatuan awal apersepsi transendetal yang ada di tiap representasi" (Derrida, 2008: 92) Ringkasnya, "Aku" adalah berpikir itu sendiri, sebab bagi Kant (2006: 15) "kemampuan ini (berpikir) adalah pemahaman."

Selain itu, menurut Bourke (2013:8), Kant membedakan manusia dengan makhluk lain berdasarkan kemampuannya untuk memanipulasi benda-benda untuk tujuannya, kemampuan pragmatisnya untuk menggunakan manusia lain untuk tujuannya, dan kemampuan moralnya untuk bisa memperlakukan dirinya dan orang lain sesuai prinsip kebebasan di bawah hukum. Dengan begini, Kant masih sama seperti 
pemikir sebelumnya yang mendefinisikan perbedaan manusia dari kapasitas rasionalnya yang tidak dimiliki hewan.

Berdasarkan basis tersebut, bagi Kant, apa yang bukan manusia adalah benda. Seorang manusia memiliki otoritas terhadap hewan yang irasional sebab hewan adalah benda. Manusia bisa menggunakannya dan menguasainya. Ini karena manusia adalah entitas yang berbeda, baik dari tingkatannya ataupun kehormatannya, dari hewan yang irasional.

Dari eksplorasi terhadap beberapa pemikiran penting dalam tradisi filsafat Barat, terlihat bahwa presuposisi paling kental dalam mendefinisikan pembedaan manusia dan hewan ialah pada kapasitas manusia untuk berpikir (akal budi) dan bahasa. Dari Aristoteles hingga Kant, bahasa menjadi aspek penting yang membedakan manusia dan hewan. Meski begitu, sejak abad 18, seperti diidentifikasi Agamben (2002: 24) dan Bourke (2013: 6), penanda yang diasumsikan membedakan manusia dan hewan menjadi problematis. Semakin sulit mencari pembeda manusia dari hewan. Bahasa yang awalnya dianggap sebagai pembeda dipermasalahkan karena ada yang menyatakan bahwa burung juga bisa berbicara. Menurut Agamben (2002: 24), bahkan perbedaan secara fisik manusia dan spesies lain semakin sulit untuk ditentukan.

Dalam keadaan inilah, Ernst Haeckel mencoba mencari pembenaran atas perbedaan manusia dan hewan melalui ilmu kealaman. Dalam Anthropogenie (1874), Haeckel merekonstruksi bagaimana evolusi manusia dari ikan menuju anthropomorph pada era Miosen. Namun, menurut Agamben (2002: 34), hipotesis penting yang diajukan Haeckel adalah bagaimana ia mendeskripsikan perpindahan dari kera anthropoid yang belum berbahasa menuju manusia yang berbahasa yang disebutnya sebagai Pithecanthropus alalus. Kemudian, hipotesis ini didukung oleh penemuan Pithecanthropus erectus di pulau Jawa.

Sayangnya, usaha Haeckel ini, menurut Agamben, mengandung kontradiksi tersendiri. Agamben (2002: 34):

"Kenyataannya, perubahan dari hewan menuju manusia, meskipun penekanannya pada perbandingan anatomi dan penemuan paleontologis, dihasilkan dari menentukan elemen yang tidak ada hubungannya apa-apa dengan keduanya, dan yang diandaikan sebagai karakteristik yang identik dengan manusia: bahasa." 
Usaha untuk mencari entitas intermedian dari hewan yang tak berbicara menuju manusia yang berbicara mengasumsikan bahwa ada manusia yang berbahasa. Dengan itu, penelusurannya mencoba mencari apa yang manusia namun belum manusia (not yet human). Maksudnya, usaha ini tidak dimulai dari nol, tapi sudah mengasumsikan sosok manusia yang berbahasa. Agamben (2002: 36) mengkritik usaha ini dengan menyatakan bahwa:

\begin{abstract}
"Apa yang membedakan manusia dari hewan adalah bahasa, tapi ini bukanlah sesuatu hal yang terberi secara alami [natural given] yang ada secara inheren dalam struktur psikososial manusia; bahasa, justru sebaliknya, adalah produk sejarah yang tidak bisa disematkan pada manusia atau hewan. Jika bahasa dibuang, perbedaan antara hewan dan manusia hilang, kecuali dibayangkan manusia yang tidak berbicara--lebih jelasnya Homo alalus, yang berfungsi sebagai jembatan perubahan hewan ke manusia. Namun, semua bukti menunjukkan bahwa ini hanyalah bayang-bayang bahasa, sebuah andaian [presuppositions] mengenai manusia yang berbicara, yang darinya kita selalu memperoleh hewanisasi manusia [animalization of man] (hewan-manusia, seperti kera-manusia-nya Haeckel) atau manusiaisasi hewan (manusia-kera). Keduanya adalah dua sisi dari satu patahan yang sama, yang tidak bisa diperbaiki dari kedua sisi."
\end{abstract}

Agamben menunjukkan bahwa pendefinisian pembedaan manusia dan hewan melalui suatu karakteristik tertentu adalah hal yang problematis. Seperti apa yang juga telah Derrida katakan bahwa distingsi manusia-hewan dibentuk oleh definisi mengenai apa yang 'proper of man.' Derrida (2004: 66):

"Tidak satupun dari ciri-ciri yang dianggap mungkin untuk mengetahui 'apa yang benar-benar manusia' ['proper of man'] oleh filsafat atau kebudayaan yang paling berwenang sekali pun--tidak satupun di antaranya, dengan segala ketelitiannya [rigor], adalah apa yang eksklusif milik apa yang oleh kita manusia sebut sebagai manusia. Entah karena beberapa hewan memilikinya, atau karena manusia tidak memiliki ciri-ciri seperti yang diklaim."

Penjelasan sejauh ini semakin menegaskan tesis Bourke bahwa definisi manusia yang membedakan diri dengan hewan adalah hal yang tak stabil dan problematis. Pembedaan itu juga disokong oleh kategori yang tidak bisa dipertahankan dengan kokoh secara filosofis dan saintifik. 


\section{B. Distingsi}

Jika pembedaan manusia dan hewan, terlebih lagi definisi mengenai manusia itu sendiri, problematis, apa fungsi sebenarnya fungsi distingsi tersebut secara filosofis? Agamben (2002: 37) berargumen bahwa pendefinisian manusia dengan metode oposisional, yakni dengan membedakan manusia-hewan, berfungsi melalui eksklusi dan inklusi. Inilah yang disebut Agamben sebagai mesin antropologis (anthropological machine). Agamben membedakan dua mode mesin antropologis bekerja: memanusiakan hewan (humanization of animal) dan menghewankan manusia (animalization of human). Mode pertama, menurut Agamben, bekerja pada era sebelum Modern, dari Aristoteles hingga Linnaeus. Mode ini menentukan apa yang manusia dari hewan, sebab, pada dasarnya, manusia adalah hewan. Dengan begitu, karakteristik manusiawi itu yang membedakan manusia dari hewan. Contoh yang diberikan Agamben adalah manusia-kera, budak, barbar, dan orang asing. Mereka dilihat sebagai hewan yang bukan manusia. Mode kedua bekerja pada zaman Modern. Mode ini mengeksklusi yang bukan manusia dari manusia itu sendiri. Maksudnya, mode ini mencari apa yang bukan manusia dari manusia. Mode ini menetapkan manusia terlebih dahulu, kemudian mengeksklusi apa yang belum manusia (not yet human) atau bukan manusia (nonhuman). Contohnya adalah Homo Alalus, manusia yang tidak berbicara. Ada juga sosok Yahudi dalam imaji Nazi Jerman yang dipandang sebagai sub-manusia. Mereka adalah manusia yang tidak memiliki karakteristik-karakteristik yang proper.

Poin penting yang disampaikan Agamben adalah bahwa kedua mode tersebut berfungsi dengan menciptakan zona kosong (zone of indifference). Seperti dikatakan Agamben, zona kosong yang berfungsi sebagai state of exception ini benar-benar kosong. Agamben (2002: 38): "zona ini, sebenarnya, kosong sempurna, dan manusia yang sesungguhnya yang menempati tempat itu terus-menerus diperbarui." Sehingga, apa yang dilakukan mesin itu bukanlah "menunjukkan karakteristik manusia yang benar-benar unik yang memberikan pemisahan jelas antara manusia dan seluruh hewan nonmanusia." (Calarco, 2009: 94) Hal ini juga semakin memperkuat tesis Bourke bahwa pendefinisian itu tidak pernah stabil karena selalu diperbarui.

Dengan ini, distingsi manusia-hewan, menurut Calarco, berada pada locus yang sangat politis dan etis. Dari argumen Agamben, Calarco menarik kesimpulan bahwa "menentukan apa yang menentukan sesuatu dapat dikatakan "manusia" dan "hewan" bukan hanya persoalan saintifik dan ontologis yang netral." (Calarco, 2009: 94) Derrida berbicara mengenai hal yang sama. la mengatakan bahwa relasi manusia harus berubah. "Relasi itu harus berubah, dalam konteks kemestian "ontologis" ("ontological" 
necessity) dan juga "etis." (Derrida, 2004: 64) Bagi Calarco, Derrida, dan Agamben, distingsi itulah yang menjadi gerbang pembuka eksploitasi/kekerasan/biopolitik pada makhluk nonmanusia, terlebih lagi hewan. Distingsi ontologis itu berhubungan pula dengan distingsi etis.

Dengan begini, problem mengenai hewan beranjak dari ontologi menuju etika. Derrida (2004:64--65) menyatakan bahwa

$$
\begin{aligned}
& \text { "konsep subjek manusia saat ini, dari subjektivitas manusia } \\
& \text { post-Cartesian, adalah pondasi dari konsep hak asasi manusia...Warisan } \\
& \text { Cartesian menentukan keseluruhan modernitas...Konsep modern } \\
& \text { mengenai hak bergantung secara besar kepada momen cogito Cartesian, } \\
& \text { subjektivitas, kebebasan, kedaulatan, dlsb." }
\end{aligned}
$$

Dari sini, bisa disimpulkan bahwa hewan bukanlah subjek hukum. Sebagaimana disampaikan Derrida (1990: 951) di teks lain: "seseorang tidak akan berbicara mengenai ketidakadilan atau kekerasan pada hewan, apalagi terhadap tumbuhan [vegetable] atau batu [stone]...Apa yang kita sebut secara asal sebagai "hewan," makhluk hidup sebagai makhluk hidup dan bukan yang lain, bukanlah subjek hukum." Dengan begitu, sesuai asumsi Cartesian dan post-Cartesian, tidak ada konsiderasi etis pada hewan. Etika, kemudian, adalah ranah yang sepenuhnya manusiawi. [Derrida dalam teks yang sama mengkritik para filsuf yang menghendaki bahwa hewan juga mesti punya hak, misal dengan deklarasi hak hewan. Pasalnya, apa yang dilakukan mereka justru memasukkan hewan pada sistem hukum yang memungkinkan kekerasan pada mereka muncul. Lebih dari itu, sistem hukum yang ada dikonstruksi berdasarkan konsep subjektivitas yang humanis. Dalam istilah Wolfe (2003: xii), diskursus hak hewan justru "secara esensial humanis."]

Pertanyaan yang muncul, kemudian, ialah: jika definisi manusia yang dilakukan dengan mode oposisional tidak bisa menentukan dengan jelas pembedaan manusia dan hewan, yang berarti bangunan konsep subjek manusia itu sendiri problematis, apakah mungkin menentukan batasan konsiderasi moral hanya untuk manusia? Atau, lebih radikal lagi, apakah mungkin menentukan batasan konsiderasi itu sendiri? Tomas Birch (1993: 315), seperti dikutip Calarco (2009: 72--73) mencatat bahwa teori moral mengasumsikan:

"(1) bahwa dalam pertimbangan moral, ada dan seharusnya ada, orang dalam (insiders) dan orang luar (outsiders), warga (citizens) dan bukan warga (non-citizens), (contohnya, budak, barbar, dan perempuan), 
"anggota kelompok" consideranda dan lainnya; (2) bahwa kita bisa dan harusnya bisa mengidentifikasi tanda, atau tanda-tanda, keanggotaan itu; (3) bahwa kita bisa mengidentifikasinya secara rasional dan tidak semena-mena [non-arbitrary]; (4) bahwa kita harusnya membentuk praktik-praktik yang menjaga tanda-tanda keanggotaan tersebut dan kesatuan kelompok, selain itu tentu memaksimalkan kebaikan untuk anggota-anggota kelompok."

Dari penjabaran tersebut, dapat diketahui bahwa manusia adalah insider dan hewan adalah outsider dari pertimbangan moral yang ada yang berlandaskan konsep subjektivitas modern. Namun, seperti yang sudah dijelaskan, tidak ada definisi yang tepat dan rigorous mengenai manusia yang oposisional dengan hewan. Tanda keanggotaan manusia dibentuk dengan negasi atau eksklusi terhadap hewan. Seperti yang dikatakan Derrida, Bourke, maupun Agamben, apa yang proper bagi manusia, atau 'tanda' bagi Birch, tidak pernah stabil. Tepat seperti apa yang dikatakan Agamben, definisi tersebut adalah zona kosong yang bisa diperbarui terus menerus. Birch memiliki pandangan yang mirip dengan Agamben. Birch (1993: 321) mencatat, seperti dikutip Calarco (2009: 72), bahwa dari perspektif historis:

\footnotetext{
"setiap kali kita menutup pertanyaan [mengenai pertimbangan moral] dengan pendirian kriteria-kriteria praktis, kita akan menemukan selanjutnya bahwa batasan itu keliru, dan kita harus membuka pertanyaan itu kembali untuk membentuk ulang praktik-praktik kita dalam usaha lebih lanjut untuk membuatnya etis."
}

Kutipan ini menunjukkan bahwa definisi itu arbriter, ditentukan secara semena-mena, dan tidak ada batasan yang jelas, sama seperti apa yang disampaikan Agamben, definisi kemanusiaan itu akan selalu diperbarui. Dengan begitu, distingsi manusia-hewan yang problematis berpengaruh pada limit pertimbangan moral yang problematis, sebab konsep manusia dan bukan manusia bisa berubah sesuai kondisi sosial, politik, ekonomi, dlsb.

\section{Penutup}

Untuk menutup tulisan ini, kesimpulan yang bisa ditarik ialah bahwa esensi kemanusiaan, yang membuatnya berbeda dari esensi kehewanan, dan distingsi manusia-hewan yang ditentukan dari definisi mengenai esensi adalah problematis. 
1. Esensi manusia yang berbeda dari hewan tidak pernah didefinisikan secara jelas, saintifik maupun filosofis. Seperti yang sudah dijelaskan, selalu ada batasan yang muncul dalam pendefinisian manusia, entah karena, mengutip Derrida kembali, "beberapa hewan memilikinya, atau karena manusia tidak memiliki ciri-ciri seperti yang diklaim." Selain itu, ada asumsi mengenai karakteristik manusiawi tertentu yang membuat usaha saintifik membuktikan keistimewaan manusia mengandung kontradiksi (lihat penjelasan Agamben). Problem lain yang menyertai hal ini adalah fakta bahwa ada banyak macam hewan dan manusia, sehingga untuk mendefinisikan "Manusia" dan "Hewan" secara umum menjadi hal yang sulit.

2. Distingsi manusia-hewan dibentuk berdasarkan definisi "manusia" dan "hewan" yang problematis membuat distingsi itu sendiri problematis. Distingsi manusia-hewan itu justru tidak pernah "hanya" distingsi "ontologis" atau "saintifik" yang netral. Distingsi itu dibentuk untuk membedakan siapa yang ikut dan tidak ikut dalam pertimbangan moral dan juga hukum. Pembedaan ini mengakar kuat dalam tradisi Cartesian dan post-Cartesian yang mendominasi diskursus modernitas.

\section{Daftar Pustaka}

Agamben, G. (2004). The Open: Man and Animal. (K. Attell, Trans.) Stanford: Stanford University Press.

Aristotle. (1984). The Complete Works of Aristotle. (J. Barnes, Ed.) Princeton: Princeton University Press.

Bourke, J. (2013). What It Means To Be Human: Reflections from 1971 to the Present. Great Britain: Virago Press.

Calarco, M. (2008). Zoographies: The Question of Animal from Heidegger to Derrida. New York: Columbia University Press.

Derrida, J., \& Rudinesco, E. (2004). For What Tomorrow: A Dialogue. (J. Fort, Trans.) Stanford: Stanford University Press.

Derrida, J. (1989). Of Spirit. (G. Bennington, \& R. Bowlby, Trans.) Chicago: The University of Chicago Press.

Derrida, J. (1990). Force of Law: The Mystical Foundation of Authority. Cardozo Law Review , 11 (919), 920-1045.

Derrida, J. (2008). The Animal That Therefore I Am. (M.-L. Mallet, Ed., \& D. Wills, Trans.) Fordham: Fordham University Press.

Descartes, R. (1985). Discourses on the Method. (R. Stoothoff, Trans.) Cambridge: Cambridge University Press. 
Kant, I. (2006). Anthropology from a Pragmatic Points of View. (R. B. Louden, Ed., \& R. B. Louden, Trans.) Cambridge: Cambridge University Press.

Timofeeva, O. (2016). The Non-Human as Such: On Men, Animals, and Barbers. On_Culture (2), 2-14.

Wolfe, C. (2003). Zoontologies: The Question of the Animal. (C. Wolfe, Ed.) Minnesota: University of Minnesota Press. 